\title{
Variasi Temporal Kelompok Ikan Terumbu Karang di Pulau Tidung Kecil Menggunakan eDNA Metabarkoding dan Sensus Visual
}

\author{
Muhammad Fahmi Zuhdi*, Hawis Madduppa, Neviaty P. Zamani \\ Departemen IImu dan Teknologi Kelautan, Fakultas Perikanan dan IImu Kelautan, IPB University \\ JI. Raya Dramaga, Kampus IPB Dramaga Bogor, Jawa Barat 16680 \\ Email: fahmizuhdi@apps.jpb.ac.id
}

\section{Abstract \\ Temporal Pattern of Coral Reef Fish Group in Tidung Kecil Island Using eDNA Metabarcoding and Underwater Visual Census}

\begin{abstract}
Coral reef fish are play key role in coral reef ecosystem. The presence of reef fish affected by antrophogenic and natural factors, such seasonal changes. This study aimed to asess the temporal variation of coral reef fish group in Tidung Kecil Island using eDNA metabarcoding and Undewater Visual Census. This research was conducted at December 2019 (West season) and August 2020 (East season). Target group are dominated in west season (64.1\%) and east season (59.25\%) using eDNA metabarcoding. While, major group fish are the highest relative abundance in both season by using Underwater Visual Census. Family Carangidae are the highest species richness (15 species) in wet season and Serranidae (3 species) in east season, respectively. Futhermore, famili Pomacentridae are the most richness species in west and east seasons 10 and 11 species respectively. Thus, it can be concluded these two methods are effective for monitoring structure or abundance of coral reef fish based on seasonal variation.
\end{abstract}

Keywords : eDNA metabarcoding, coral reef fish, temporal variation

\begin{abstract}
Abstrak
Ikan karang menjadi indikator dalam menilai keanekaragaman hayati di ekosistem tersebut. Keberadaan ikan di ekosistem terumbu karang dapat dipengaruhi oleh faktor antropogenik dan faktor alam salah satunya perubahan musim. Penelitian ini bertujuan untuk menganalisis kelimpahan kelompok ikan terumbu karang di Pulau Tidung Kecil menggunakan eDNA metabarkoding dan Sensus Visual. Pengambilan data dilakukan pada bulan Desember 2019 (musim barat) dan Agustus 2020 (musim timur). Ikan target mendominasi pada musim barat dan timur dengan persentase sebesar $64.11 \%$ dan $59.25 \%$. Sensus visual berhasil mendeteksi ikan mayor dengan persentase tertinggi $62.5 \%$ di musim barat dan $82.8 \%$ di musim timur. Famili Carangidae merupakan famili dengan jumlah spesies tertinggi di musim barat (15 species) dan Siganidae di musim timur menggunakan eDNA metabarkoding (3 species). Hasil UVC menunjukkan famili Pomcentridae memilki jumlah spesies tertinggi di kedua musim (11 dan 10 spesies) menggundakan sensus visual. Dapat disimpulkan bahwa kedua metode tersebut dapat menjadi pendekatan dalam monitoring struktur atau kelimpahan ikan terumbu karang berdasarkan musim.
\end{abstract}

Kata Kunci : eDNA metabarkoding, ikan terumbu karang, variasi temporal

\section{PENDAHULUAN}

Salah satu biota yang mendiami ekosistem terumbu karang adalah ikan karang. Ikan karang memiliki hubungan yang erat dengan ekosistem terumbu karang (Bengen, 2013). Menurut Adrim et al (2012) ikan terumbu karang terbagi berdasarkan 
fungsi pemanfaatan dan aspek ekologi yaitu ikan target, ikan indikator, dan kelompok ikan lain-lain (major groups). Kelompok ikan indikator merupakan bioindikator untuk kesehatan ekosistem terumbu karang (Shidqi et al. 2018), sedangkan ikan target memiliki nilai ekonomis penting dan menjadi target nelayan (Edrus dan Abrar, 2017), dan ikan mayor umumnya memainkan peran penting dalam rantai makanan di ekosistem terumbu karang (Dewi et al. 2018).

Ikan terumbu karang merupakan salah satu faktor kunci dalam menilai keanekaragaman hayati pada ekosistem terumbu karang (Tony et al. 2020). Menurut (Madduppa et al. 2013) ikan terumbu karang memiliki hubungan yang sangat kuat dengan ekosistem terumbu karang. Beberapa faktor yang mempengaruhi struktur komunitas ikan yaitu aktivitas penangkapan, degradasi habitat (Knowlton dan Jackson, 2008), perubahan lingkungan (Plass-Johnson et al. 2015; Polónia et al. 2019) dan pengaruh musim. Menurut Chittaro dan Sale (2003) jumlah komunitas ikan dapat bervariasi tergantung dari perbedaan musim. Beberapa telah melaporkan variasi kelimpahan ikan berdasarkan musim (Madduppa et al. 2012; Sigsgaard et al. 2017; Vaughan et al. 2021).

Kondisi keanekaragaman hayati akuatik merupakan informasi penting dalam menjelaskan berbagai proses ekologis, termasuk di antaranya untuk tujuan biomonitoring (Leray et al. 2013). Beberapa kegiatan biomonitoring telah dilakukan untuk melihat kaitan antara keanekeragaman dan kelimpahan ikan dengan ekosistem terumbu karang (Adrim et al. 2012; Madduppa et al. 2013; Tony et al. 2020). Kegiatan biomonitoring ikan terumbu karang sebagian besar dilakukan dengan metode Underwater Visual Sensus (UVC) (Stat et al. 2019). Metode ini memiliki kelemahan dalam mengidentifikasi spesies cryptic, sehingga membutuhkan keahlian yang memadai (Bozec et al. 2011), serta terbatas pada cakupan spasial dan temporal (Boussarie et al. 2018).

Teknik DNA lingkungan saat ini dapat menjadi metode alternatif yang efektif dalam menganalisis kelimpahan ikan (Thomsen et al. 2012). Analisis DNA lingkungan dapat diperoleh dari jaringan yang terkelupas, feses atau pembusukan yang dilepaskan di perairan (Takahara et al. 2013; Laramie et al. 2015; Barnes dan Turner 2016). Beberapa penelitian di berbagai lokasi menunjukkan bahwa metode metabarkoding DNA lingkungan secara efektif dan akurat dapat digunakan dalam survei komunitas ikan karang (Miya et al. 2015; Evans et al. 2016; DiBattista et al. 2017). Selain itu, eDNA memiliki tingkat keberhasilan $>90 \%$ dalam mengidentifikasi spesies (Jerde et al. 2019), dan dapat mengidentifikasi spesies cryptobentik (Brandl et al. 2018).

Kondisi oseanografi secara Oleh karena itu, metode analisis DNA lingkungan merupakan salah satu metode alternatif untuk memonitoring keanekara-gman hayati laut (Gordon et al., 2015). Umum di Kepulauan Seribu hampir sama dengan wilayah tropis lainnya, suhu perairan berkisar antara $25.6-32.3^{\circ} \mathrm{C}$, salinitas perairan sekitar 28-32\%。 (Rositasari et al. 2017). Wilayah Kepulauan Seribu umumnya dipengaruhi oleh angin muson atau angin musim yakni angin musim barat dan timur. Musim barat terjadi pada bulan Desember-Februari dan musim timur terjadi sekitar bulan Juni-Agustus, serta musim peralihan I (Maret-Mei) dan peralihan II (September-November). Variasi musim di suatu wilayah dapat menjadi salah satu faktor yang mempengaruhi ekosistem yang ada di perairan. Salah satunya ekosistem terumbu karang. Menurunnya keanekaragaman terumbu karang karena faktor alam dan antropogenik, secara tidak langsung dapat mempengaruhi keanekaragaman ikan terumbu karang (Bengen, 2013). Tujuan Penelitian ini adalah untuk menganalisis variasi temporal kelompok ikan terumbu karang di Pulau Tidung Kecil menggunakan eDNA metabarkoding dan Sensus Visual.

\section{MATERI DAN METODE}

Penelitian ini dilakukan pada bulan Desember 2019 (Musim Barat) dan Agustus 2020 (Musim Timur). Wilayah Kepulauan Seribu dipengaruhi oleh angin musim yakni musim barat (Desember-Maret) dan timur (Juli- 
Agustus) (Rositasari et al. 2017). Pengambilan sampel dilakukan di satu titik pengamatan (Gambar 1). Analisis molekuler dilakukan di Laboratorium Biodiveristas dan Biosistematika Kelautan, Departemen IImu dan Teknologi Kelautan, Fakultas Perikanan dan IImu Perikanan, Institut Pertanian Bogor.

\section{Pengambilan sampel (Visual Sensus)}

Pengambilan data ikan terumbu karang menggunakan metode belt transect (English et al. 1997). Pengambilan data dilakukan dengan penyelaman SCUBA pada lokasi yang sama dengan lokasi pengambilan sampel air laut. Ukuran garis transek untuk pengambilan data ikan yakni 50 meter. Pengambilan data dilakukan dengan underwater visual census (UVC) dengan mencatat spesies dan kelimpahan. Transek sabuk mempunyai ukuran panjang 50 meter dan lebar 5 meter, sehingga luasnya $250 \mathrm{~m}^{2}$. Identifikasi ikan mengacu pada (Allen et al. 2003) dan Froose and Pauly (2021).

\section{Pengambilan Sampel Air Laut (eDNA)}

Pengambilan sampel berupa air yang berada di bagian sedimen (Madduppa et al. 2020) menggunakan botol sampel volume 1 L. Sampel air kemudian dilakukan proses penyaringan menggunakan seperangkat alat penyaring berupa Peritaltic Pump masterflex nomor 13-310-662 dan disaring menggunakan kertas milipore $0.4 \mu \mathrm{m}$ (Bakker et al. 2017). Kertas saring dipotong

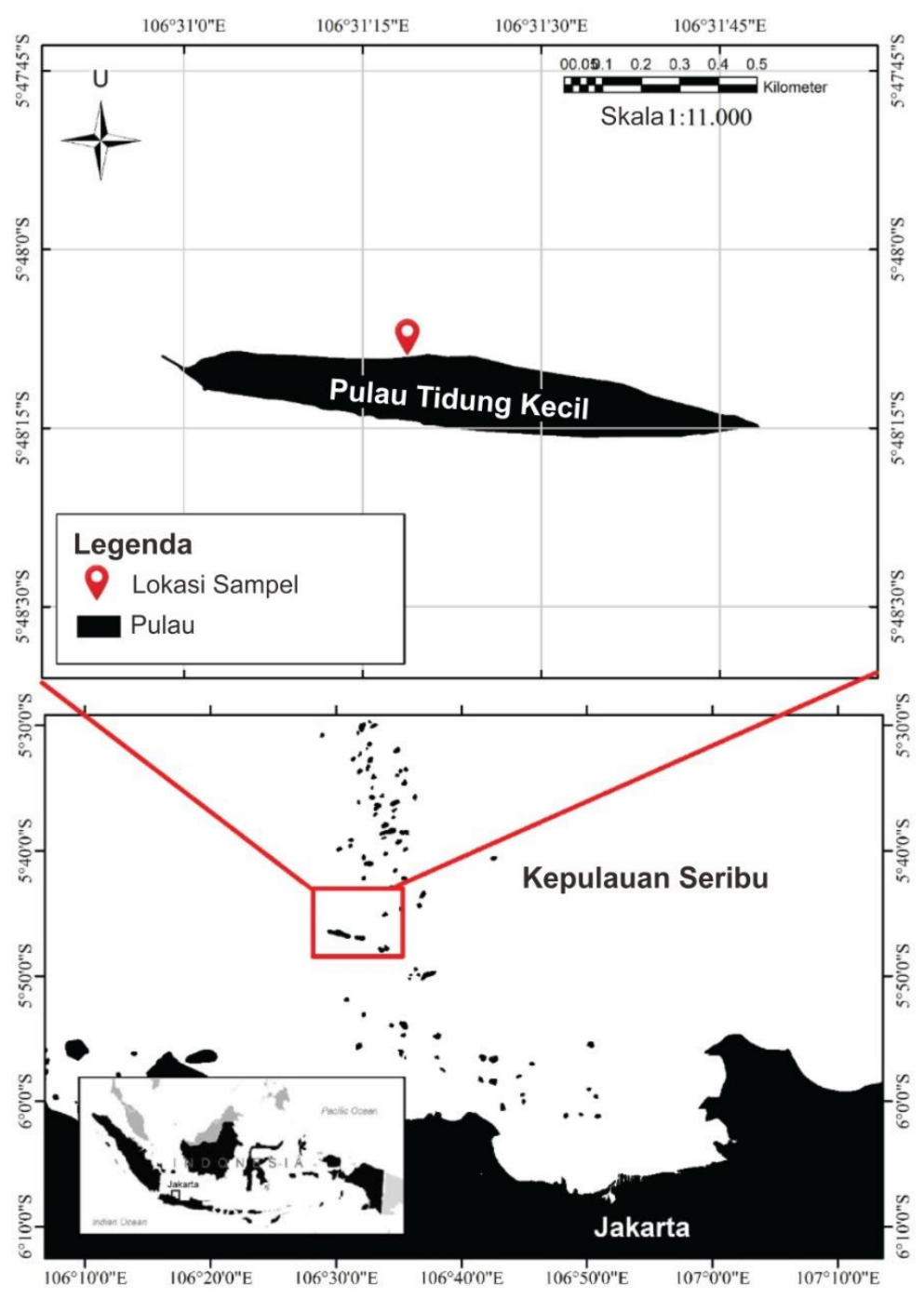

Gambar 1.Peta Lokasi Penelitian poin merah merupakan lokasi pengambilan sampel 
menjadi dua bagian menggunakan alat pemotong berupa gunting yang telah disterilisasi dengan larutan bleach $70 \%$, yang merupakan replikasi (Pesant et al. 2015; Gimmler et al. 2016) Kertas saring dimasukkan ke dalam $2 \mathrm{ml}$ cryotube yang telah di isi dengan cairan DNA Shield $\pm 1 \mathrm{ml}$ yang bertujuan untuk mengawetkan sampel.

\section{Analisis Molekuler}

Proses ekstraksi sampel eDNA menggunakan metode kit ZR Soil DNA Miniprep (Zymo Research, USA) sesuai protokol pabrik (Verma dan Satyanarayana 2011; Li et al. 2018). Sampel yang diekstraksi berupa kertas saring yang digunakan untuk menyaring sedimen. Amplifikasi DNA atau Polymerase Chain Reaction (PCR) dilakukan dengan menggunakan Primer MiFish-U-Fadapt dan MiFish-U-R-adapt (Miya et al. 2015). Komponen dalam reaksi $P C R$ adalah $12.5 \mu \mathrm{l}$ MyTaq HS Redmix (BIOLINE), $1.25 \mu \mathrm{l}$ primer forward dan reverse, $9 \mu \mathrm{l} \mathrm{H}_{2} \mathrm{O}$, dan $1 \mu \mathrm{l}$ sampel DNA, dengan total volume $25 \mu \mathrm{l}$. Proses PCR menggunakan Thermo Cycler dengan kondisi yaitu denaturasi awal $95^{\circ} \mathrm{C}$ selama 3 menit, kemudian dilanjutkan dengan 35 siklus PCR yang terdiri dari tahap denaturasi pada suhu $98^{\circ} \mathrm{C}$ selama 20 detik, tahap annealing primer pada suhu $65{ }^{\circ} \mathrm{C}$ selama 15 detik dan tahap elongasi pada suhu $72^{\circ} \mathrm{C}$ selama 15 detik. Setelah 35 siklus PCR, kemudian dilanjutkan dengan tahap elongasi akhir pada suhu $72^{\circ} \mathrm{C}$ selama 10 menit.

Tahap kedua amplifikasi disebut library preparation. Pada tahap ini, sampel DNA yang telah melewati PCR tahap satu kemudian dilakukan quality control untuk memastikan sampel DNA yang digunakan memiliki kualitas yang baik sehingga hasil yang diperolah akan lebih akurat. Selanjutnya pada tahap ini, sampel DNA disisipkan index (identitas sampel) dengan menggunakan Nextera XT index kit. Komponen reaksi PCR kedua menggunakan 2x KAPA HiFi HotStart ReadyMix. Proses PCR kedua menggunakan Thermo Cycler dengan kondisi yaitu denaturasi awal $95^{\circ} \mathrm{C}$ selama 3 menit kemudian dilanjutkan dengan 12 siklus PCR yang terdiri dari tahap denaturasi $98^{\circ} \mathrm{C}$ selama 12 detik, tahap annealing primer pada suhu $98^{\circ} \mathrm{C}$ selama 20 detik dan tahap elongasi pada suhu $72{ }^{\circ} \mathrm{C}$ selama 30 detik. Setelah 12 siklus PCR, kemudian dilanjutkan dengan tahap elongasi akhir pada suhu $72^{\circ} \mathrm{C}$ selama 5 menit. Proses elektroforesis menggunakan gel agarosa $1.5 \%$ dan etidium bromida, menggunakan perangkat elektroforesis selama 20 menit pada tegangan $120 \mathrm{~V}$. Pita hasil elektroforesis divisualisasi dengan menggunakan sinar ultraviolet di UV transilluminator. Produk PCR yang positif dikirim ke Genetica Science untuk dilakukan tahapan sekuensing dengan menggunakan Next Generation Sequencing Illumina Nexseq 500.

\section{Analisis Bioinformatik}

Hasil dari produk sekuensing menggunakan tehnik Illumina Nexseq berupa file fastQ dianalsisi menggunakan perangkat lunak online MiFish Pipeline MiFish Pipeline (Sato et al., 2018) dengan output berupa reads/sekuens dengan tingkat similaritas diatas 97\%, dan 80-97\%. Tahapan yang dikerjakan pada MiFish Pipeline adalah pemotongan basa awal dan akhir dari sekuens, penyatuan dua reads yaitu $R l$ dan R2 (merging), Filterisasi pada basa yang tidak terbaca atau yang dikenal sebagai $\mathrm{N}$ serat memfilter panjang reads dalam sekuens, proses penghapusan primer dalam sekuens, proses clustering yang membagi sekuens kedalam kelompok cluster, dan penentuan kesamaan sekuens terhadap data set. Kelimpahan individu ikan berdasarkan famili dan spesies mengacu pada (Miya et al. 2015). Ikan yang telah terdeteksi kemudian di kelompokkan menjadi tiga kategori yaitu: Ikan indikator, ikan target, dan ikan mayor. Identifikasi jenis ikan berdasarkan kategori kelompok ikan mengikuti FishBase (Froese dan Pauly 2021).

\section{Analisis Data}

Ikan karang yang ditemukan menggunakan metode sensus visual diidentifikasi jenisnya berdasarkan buku identifikasi (Allen et al. 2003) dan (Froese dan Fauly 2021). Selanjutnya ikan dikategorikan berdasarkan kelompok. Ikan yang telah diidentifikasi, kemudian dihitung kelimpahannya berdasarkan jenis dan 
kelimpahan relatifnya (Odum 1998). Uji $\dagger$ dilakukan untuk melihat perbedaan antara

\section{HASIL DAN PEMBAHASAN}

Kelompok ikan terumbu karang yang terdeteksi menggunakan analisis eDNA metabarkoding dan UVC berbeda signifikan pada kelimpahan dan komposisi kelompok ikan terumbu karang antara eDNA metabarkoding dan sensus visual $p<0.05$. Perbedaan hasil ini diduga disebabkan karena perbedaan metode yang digunakan. Hasil menunjukkan bahwa UVC hanya mengobservasi ikan yang berasosiasi dengan terumbu karang. Sedangkan eDNA metabarkoding dapat mendeteksi jenis ikan yang tidak menetap di terumbu karang seperti (Sardinella lemuru, Auxis thazard, dan Rastrelliger brachysoma), dan beberapa spesies cryptobentik (Enneapterygius leucopunctatus, Pandaka pygmaea) umumnya kelompok cryptobentik susah untuk diidentifikasi ( Brandl et al. 2018). Selain itu, kelimpahan dan komposisi kelompok ikan terumbu karang dapat disebabkan oleh pengambilan sampel dan area sampling (Bengen, 2013).

Hasil analisis menggunakan eDNA pada musim barat dan timur kelimpahan relatif tertinggi kelompok ikan terumbu karang menggunakan eDNA didominasi oleh kelompok ikan target yakni 134 jenis (64.11\%) metode eDNA dan UVC.

di musim barat dan 16 jenis (59.25\%) di musim timur (Gambar 2). Ikan target merupakan kelompok ikan yang menjadi target nelayan karena memiliki nilai ekonomis penting (Madduppa et al. 2014). Famili Carangidae merupakan famili dengan jumlah spesies terbanyak di musim barat dan timur dengan 15 spesies, Tingginya jumlah jenis dari famili Carangidae diduga disebabkan karena aktivitas penangkapan di lokasi tersebut. Pada musim barat aktivitas penangkapan cenderung menurun pada ikan-ikan target nelayan dikarenakan cuaca buruk pada musim barat cenderung membahayakan nelayan (Martasari et al. 2010). Selain itu, tingginya kehadiran famili Carangidae di ekosistem terumbu karang diduga disebabkan oleh fungsi ekologis ekosistem terumbu karang. Ekosistem terumbu karang dapat dimanfaatkan oleh biota-biota laut seperti ikan sebagai tempat mencari makan, memijah dan pembesaran (Madduppa et al. 2012).

Hasil analisis menggunakan sensus visual atau UVC menunjukkan bahwa ikan mayor memiliki persentase kelimpahan relatif tertinggi di kedua musim $62.5 \%$ dan $82.8 \%$ (Gambar 3). Hal ini sesuai dengan penelitian yang dilakukan oleh Harsindhi et al. (2020) yang melaporkan kelimpahan ikan mayor mendominasi di ekosistem terumbu karang.

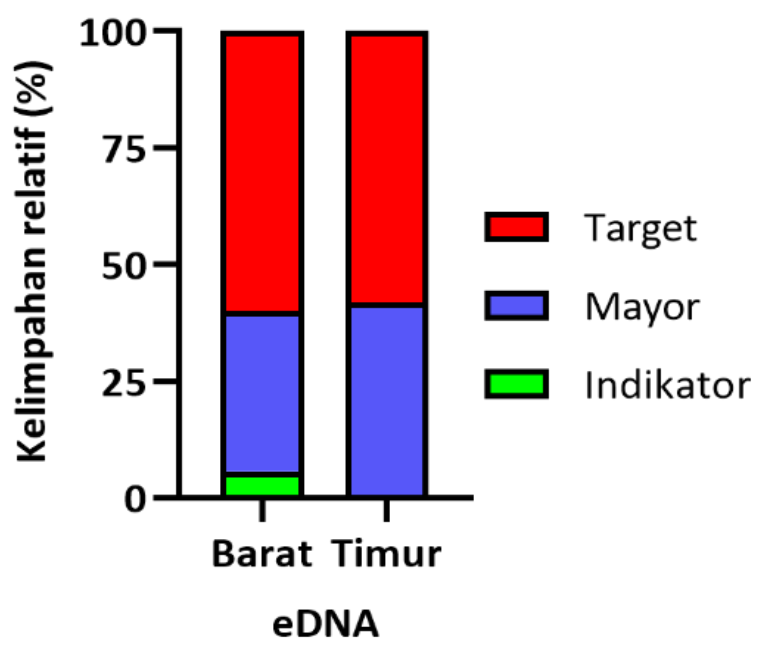

Gambar 2. Kelimpahan relatif ikan terumbu karang berdasarkan kelompok menggunakan eDNA di musim barat dan timur. 


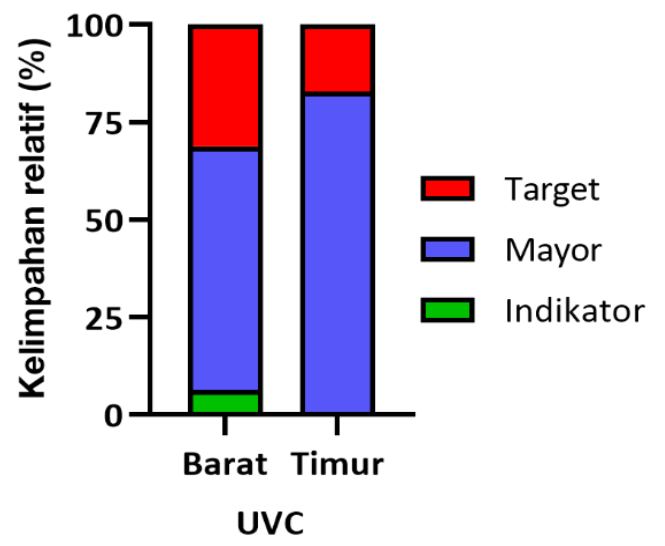

Gambar 3. Kelimpahan relatif ikan terumbu karang berdasarkan kelompok menggunakan UVC di musim barat dan timur.

Kelompok ikan mayor memiliki kelimpahan tertinggi di ekosistem terumbu karang (Taira et al. 2013). Famili Pomacentridae merupakan kelompok ikan mayor dengan jumlah spesies tertinggi dengan jumlah 10 spesies di musim barat dan 11 spesies di musim timur. Famili Pomacentridae merupakan famili yang memiliki kecocokan fisiologi dengan ekosistem terumbu karang (Rungkat et al. 2013), dan berperan penting dalam jaring-jaring makanan (Edrus dan Abrar, 2017).

Hasil identifikasi menggunakan eDNA dan UVC ditemukan bahwa kelompok ikan indikator sedikit terdeteksi menggunakan kedua metode baik di musim barat dan musim timur. (Gambar 2 dan 3). Salah satu kelompok ikan indikator yakni famili Chaetodontidae. Famili ini merupakan salah satu bioindikator dalam menilai kesehatan terumbu karang. Rendahnya jumlah jenis ikan indikator yang ditemukan diduga disebabkan karena preferensi habitat yang digunakan oleh kelompok ikan tersebut. Ikan terumbu karang memilki kecendrungan untuk memilih habitat berdasarkan lifeform atau bentuk terumbu karang itu sendiri (Harsindhi et al. 2020).

\section{KESIMPULAN}

Kelompok ikan target memilki kelimpahan tertinggi di musim barat dan timur menggunakan eDNA, sedangkan kelompok ikan mayor mendominasi di musim barat dan timur menggunakan UVC.
Terdapat perbedaan yang signifkan antara metode eDNA dan UVC. eDNA dan UVC merupakan dua metode yang saling melengkapi satu sama lain dalam mengamati atau monitoring kelompok ikan di ekosistem terumbu karang.

\section{DAFTAR PUSTAKA}

Adrim, M., Harahap, S.A. \& Wibowo, K., 2012. Struktur Komunitas Ikan Karang di Perairan Kendari. IImu Kelautan: Indonesian Journal of Marine Sciences, 17(3):154-163. doi: 10.14710/ ik.ijms.17.3.154-163.

Allen, G.R., Steen, R., Human, P. \& Deloach, N, 2003. Reef Fish Identification (Tropical Pacific). New World Publication. Florida USA.

Bakker, J., Wangensteen, O.S., Chapman, D.D., Boussarie. G., Buddo. D., Guttridge. T.L., Hertler, H., Mouillot, D., Vigliola, L. \& Mariani, S, 2017. Environmental DNA Reveals Tropical Shark Diversity In Contrasting Levels of Anthropogenic Impact. Scientific Reports. 1:1-11. doi: 10.1038/s41598-01 7-17150-2.

Bengen, D.G, 2013. Coral Reef Bio-Ecology Status And Challange. IPB Press, Indonesia, pp 62-74.

Boussarie, G., Bakker, J., Wangensteen, O.S., Mariani, S., Bonnin, L., Juhel, J.B., Kiszka, J.J., Kulbicki, M., Manel, S., Robbins, W.D. \& Vigliola, L 2018. Environmental DNA illuminates the dark diversity of sharks. Science Advances. 4(5):p.eaap9661. doi: 10. $1126 /$ sciadv.aap 9661. 
Bozec, Y.M., Kulbicki, M., Laloë, F., MouTham, G. \& Gascuel, D, 2011 . Factors affecting the detection distances of reef fish: Implications for visual counts. Marine Biology, 158(5):969-981. doi: 10.1007/s00227-01 1-1623-9.

Brandl, S.J., Goatley, C.H., Bellwood, D.R. \& Tornabene, L. 2018. The hidden half: Ecology and evolution of cryptobenthic fishes on coral reefs. Biological Reviews, 93(4):1846-1873. doi: $10.1111 / \mathrm{brv} .12423$.

Dewi, C.S.U., Sukandar, Harsindhi, C.J. 2018 Reef-fish in Bawean Island. UB Press, Malang, Indonesia, 123.

DiBattista, J.D., Coker, D.J., Sinclair-Taylor, T.H., Stat, M., Berumen M.L. \& Bunce M, 2017. Assessing the utility of eDNA as a tool to survey reef-fish communities in the Red Sea. Coral Reefs. 36(4):1245-1252. doi: 10.1007/ s00338-017-1618-1.

Edrus, I.N. \& Abrar, M.A, 2017. Diversity of Reef Fish Fungsional Groups in Terms of Coral Reef Resiliences. Indones Fish Res J. 22(2):109. doi: 10.15578/ifrj.22.2. 2016.109122.

English, S., Wilkinson, C. \& Baker, V., 1997. Survey Manual for Tropical Marine Resources, 2nd edn. Australia Institute of Marine Science, Townsville (AU).

Evans, N.T., Olds, B.P., Renshaw, M.A., Turner, C.R., Li, Y., Jerde, C.L., Mahon, A.R., Pfrender, M.E., Lamberti, G.A. \& Lodge, D.M, 2016. Quantification of mesocosm fish and amphibian species diversity via environmental DNA metabarcoding. Molecular Ecology Resources. 16(1):2941. doi: 10.1111/1755-0998.12433.

Froese, R. \&Pauly, D. 2021. FishBase. World Wide Web electronic publication. www.fishbase.com. Accessed 20 January 2021.

Harsindhi, C.J., Bengen, D.G., Zamani N.P., Kurniawan, F. (2020). Abundance and spatial distribution of reef fish based on coral lifeforms at tidung island, Seribu Islands, Jakarta Bay. AACL Bioflux. 13(2):736-745.

Jerde, C.L., Wilson, E.A. \& Dressler, T.L. 2019. Measuring global fish species richness with eDNAmetabarcoding. 19:19-22. doi: $10.1111 / 17550998.12929$.

Knowlton, N. \& Jackson, J.B.C, 2018. Shifting baselines, local impacts, and global change on coral reefs. PLOS Biol. 6:54. doi: 10.1371/journal.pbio.00 60054 .

Laramie, M.B., Pilliod, D.S., Goldberg, C.S. \& Strickler, K.M, 2015. Environmental DNA sampling protocol - filtering water to capture DNA from aquatic organisms. Tech Methods. doi: 10.313 3/tm2a13.

Leray, M., Yang, J.Y., Meyer, C.P., Mills, S.C., Agudelo, N., Ranwez, V., Boehm, J.T. \& Machida, R.J, 2013. A new versatile primer set targeting a short fragment of the mitochondrial $\mathrm{COl}$ region for metabarcoding metazoan diversity: Application for characterizing coral reef fish gut contents. Front Zool. 10(1):1-14. doi:10.1186/1742-9994-10-34.

Li, Y., Evans, N.T., Renshaw, M.A., Jerde, C.L., Olds, B.P., Shogren, A.J. \& Pfrender, M.E. 2018. Estimating fish alpha and beta diversity along a small stream with environmental DNA metabarcoding. Metabarcoding and Metagenomics. 2:e24262. doi: 10.38 97/mbmg.2.24262.

Odum, E.P. 1998. Fundamental ecology. Gajah Mada University Press, Yogyakarta.

Madduppa, H.H., Subhan, B., Suparyani, E., Siregar, A.M., Arafat, D., Tarigan, S.A., Alimuddin, Khairudin, D., Rahmawati F. \& Bramandito, A 2013. Dynamics of fish diversity across an environmental gradient in the Seribu Islands reefs off Jakarta. Biodiversitas Journal of Biological Diversity, 14(1):17-24. doi: 10.13057/biodiv/d 140103.

Madduppa, H.H., Ferse, S.C., Aktani, U. \& Palm, H.W., 2012. Seasonal trends and fish-habitat associations around Pari Island, Indonesia: Setting a baseline for environmental monitoring. Environmental biology of fishes, 95(3):383-398. doi: 10.1007/s10641-01 2-0012-7.

Maddupa, H.H. 2014. Bioekologi dan Biosistematika Ikan Terumbu: Studi Kasus Kepulauan Seribu. Bogor (ID): IPB Press.

Madduppa, H. \& Sani, L.M.I. 2020. Environ-mental DNA Sampling Protocol. Department of Marine Science and Technology Faculty of Fisheries and Marine Sciences. Institut Pertanian Bogor.

Miya, M., Sato, Y., Fukunaga, T., Sado, T., Poulsen, J.Y., Sato, K., Minamoto, T., Yamamoto, S., Yamanaka, H., Araki, H. \& Kondoh, M. 2015. MiFish, a set of universal PCR primers for metabarcoding 
environmental DNA from fishes: Detection of more than 230 subtropical marine species. Royal Society open science, 2(7):p.150088 doi: 10.1098/rsos. 150088.

Pesant, S., Not, F., Picheral, M., Kandels-Lewis, S., Le Bescot, N., Gorsky, G., Iudicone, D., Karsenti, E., Speich, S., Troublé, R. \& Dimier, C.2015. Open science resources for the discovery and analysis of Tara Oceans data. Nature. 2:150023. doi: 10.1038/sdata. 2015.23.

lass-Johnson, J.G., Taylor, M.H., Husain, A.A., Teichberg, M.C. \& Ferse, S.C., 2016. Non-random variability in functional composition of coral reef fish communities along an environmental gradient. PLOS ONE 11:1-18. doi: 10.1371/journal.pone. 0154014.

Polónia, A.R.M., Cleary, D.F.R., Duine, A.A., Van Dijk, J. \& De Voogd, N.J. 2019. Assessment of fish community structure along the Jakarta Bay-Pulau Seribu reef complex. Journal of the Marine Biological Association of the United Kingdom, 99(2):503-516.

Rositasari, R., Puspitasari, R., Nurhati, I.S., Purbonegoro, T. \& Yogaswara, D. 2017. Review Penelitian di Teluk Jakarta. Pusat Penelitian Oseanografi, LIPI. Jakarta Utara.

Rungkat, V.M.E., Tamanampo, J.F.W.S. \& Tombokan, J.L. 2013. Community structure of Pomacentridae fish in Coastal Waters on Malalayang Dua Village of Manado Gulf. Jurnal IImiah Platax,1:125-131.

Sato, Y., Miya, M., Fukunaga, T., Sado, T., \& Iwasaki, W. 2018. MitoFish and mifish pipeline: A mitochondrial genome database of fish with an analysis pipeline for environmental DNA metabarcoding. Molecular Biology and Evolution, 35(6): 1553-1555. doi: 10.1093/molbev/msy074.

Sigsgaard, E.E., Nielsen, I.B., Carl, H., Krag, M.A., Knudsen, S.W., Xing, Y., HolmHansen, T.H., Møller, P.R. \& Thomsen, P.F. 2017. Seawater environmental DNA reflects seasonality of a coastal fish community. Marine Biology, 164(6): p128 doi: 10.1007/s00227-017-3147-4.
Shidai, R.A., Pamuji, B., Sulistiantoro, T., Risza, M., Faozi, A.N., Muhammad, A.N., Muharam, M.R., Putri, E.D., Hartini, R., Valentina, B. \& Fakhri, R.Z., 2018. Coral health monitoring at Melinjo Island and Saktu Island: Influence from Jakarta Bay. Regional Studies in Marine Science, 18:237-242.

Stat, M., John, J., DiBattista, J.D., Newman, S.J., Bunce, M. and Harvey, E.S., 2019. Combined use of eDNA metabar-coding and video surveillance for the assessment of fish biodiversity. Conservation Biology, 33(1):196-205. doi: 10.1111/cobi.13183.

Taira, D., Poquita-Du, R.C., Toh, T.C., Toh, K.B., Ng, C.S.L., Afiq-Rosli, L., Chou, L.M. \& Song, T., 2018. Spatial variability of fish communities in a highly urbanised reef system. Urban Ecosystem, 21 (1):85-95.

Takahara, T., Minamoto, T. \& Doi, H.,2013. Using Environmental DNA to Estimate the Distribution of an Invasive Fish Species in Ponds. PLoS One. 8(2): p.e56584. doi: 10.1371/journal.pone. 0056584.

Tony, F., Soemarno, Wiadnya, D.G.R. \& Hakim, L. 2020. Diversity of reef fish in halang melingkau island, South Kalimantan, Indonesia. Biodiversitas. 21(10):48044812. doi: 10.13057/bio div/d211046.

Thomsen, P.F., Kielgast, J., Iversen, L.L., Møller, P.R., Rasmussen, M. \& Willerslev, E. 2012. Detection of a Diverse Marine Fish Fauna Using Environmental DNA from Seawater Samples. PLOS One. 7(8):1-9. doi: 10.1371/journal.pone.0041732.

Vaughan, G.O., Shiels, H.A. \& Burt, J.A. 2021. Seasonal variation in reef fish assemblages in the environmentally extreme southern Persian/Arabian Gulf. Coral Reefs. 40(2):405-416. doi: 10.1007/s00338-020-02041-2.

Verma, D. \& Satyanarayana, T. 2011. An improved protocol for DNA extraction from alkaline soil and sediment samples for constructing metagenomic libraries. Applied Biochemistry and Biotechnol. 165:454-464. doi: 10.1007/ s12010-0119264-5. 